\title{
Corporate Social Responsibility in Sustainable Supply Chain Management: An Econo-Bibliometric Perspective
}

\author{
Christophe Schinckus ${ }^{1}$, Mohammadreza Akbari², Steve Clarke ${ }^{2}$ \\ ${ }^{1}$ Taylor's Business School, Taylor's University, Subang Jaya, Malaysia \\ ${ }^{2}$ Department of Management, RMIT University Vietnam, Ho Chi Minh, Vietnam \\ Email: Christophe.Schinckus@taylors.edu.my, reza.akbari@rmit.edu.vn, steven.clarke@rmit.edu.vn
}

How to cite this paper: Schinckus, C., Akbari, M. and Clarke, S. (2019) Corporate Social Responsibility in Sustainable Supply Chain Management: An Econo-Bibliometric Perspective. Theoretical Economics Letters, 9, 247-270.

https://doi.org/10.4236/tel.2019.91020

Received: December 12, 2018

Accepted: February 19, 2019

Published: February 22, 2019

Copyright () 2019 by author(s) and Scientific Research Publishing Inc. This work is licensed under the Creative Commons Attribution International License (CC BY 4.0).

http://creativecommons.org/licenses/by/4.0/

\begin{abstract}
This paper identifies and synthesizes information from academic journals, and examines the importance of corporate social responsibility (CSR) in supply chain management (SCM) literature. By using keywords such as "corporate social responsibility", "corporate citizenship" and "supply chain" in the major online publishers' database from 2006 to 2016, our study shows increasing importance of CSR topic in logistics and supply chain management. This growing trend has been observed at different levels (theoretical, geographical and industrial). Many moral and societal aspects can explain this interest, but this article focuses on a complementary justification by suggesting a conceptual framework formalizing the economic reason for which we can observe a growing interest in CSR issues in SCM.
\end{abstract}

\section{Keywords}

Corporate Social Responsibility, Corporate Citizenship, Sustainable Development, Supply Chain Management, Financial Value

\section{Introduction}

This article deals with the importance of corporate social responsibility (CSR) in supply chain management. Roughly speaking, corporate social responsibility refers to a concept whereby companies integrate social and environmental concerns in their business operations and interactions with their stakeholders. Corporate social responsibility is generally understood as being the way through which "a company achieves a balance of economic, environmental and social imperatives” ([1], Para. 1). The challenge for logistics stakeholders includes var- 
ious elements: consumers, shareholders, non-governmental organizations (NGOs), regulators, unions, international logistics and supply chain firms [2] [3]. In addition to these, it is vital for firms to understand the greater scheme of their business environment while learning how to work with a complicated system of players all working towards reducing harmful elements internal and external sustainability [4]. Global companies, whether international brands, and/or manufacturers, are not new to sustainability ascendancies. As part of the bigger picture, or global scheme, supply chain (SC) practices and attitude often grapple with sustainability, accountability and complex products, services and performance measurements [5] [6].

As a result of the expansion and development of medium to large international and global companies, one can observe a growing implementation of annual reports, sustainable strategies, and updated codes of conduct (i.e., social customs, religious conventions, and obligations) reflecting additional interest in supply chain sustainability [7] [8]. These items contribute to the triple bottom line (i.e., social, environmental, and financial), corporate greening (i.e., operationally environmentally responsible), green logistics (i.e., reduction of ecological effects), and CSR [9].

The objective of this paper is twofold: on the one hand, to map the current importance of the CSR and sustainable chain management in the current literature and, on the other hand to offer an economic perspective justifying the growing interest in CSR practices. For this purpose, in a first step, we investigate academic journals dealing with supply chain management (SCM) practices in industry. Such approach gives us a range of databases from 2006 to 2016, containing the words, "corporate social responsibility", and "supply chain" in the title or abstract.

Such analysis will help us to identify a trend in the potential increasing importance of CSR in supply chain management. That will be the first contribution of this article: to see if, in a context in which CSR became buzz-word, this issue is increasingly important or not in the literature.

The paper is structured as follows. The following section offers an overview of the literature dealing with CSR practices in logistics. It is worth mentioning that this article is not a literature review on the CSR in the literature dealing with supply chain management, but it rather uses systematic review of documents/works as a methodology to identify a trend and to suggest the reasons to this trend. Afterwards, we detail our methodology before discussing our data analysis. Finally, the last section suggests an economic justification for this growing interest in CSR issues in logistics. With this purpose, we introduce a conceptual framework illustrating the influence of CSR practices on the financial value of companies.

\section{Overview of Surveys on Corporate Social Responsibility}

In 1970, in his essay "The Social Responsibility of Business Is to Increase Its 
Profits" Milton Friedman wrote the following: "There is one and only one social responsibility of business to use its resources and engage in activities designed to increase its profits, so long as it remains within the rules of the game, which is to say, engages in open and free competition without deception or fraud" ([10], p. 4). The primary concern for CSR is the treatment of all stakeholders, both internally and externally, to do the right thing ethically in a socially responsible way thereby enhancing human development [11]. Emblematic advances initially offered in 1999 included corporate development of 1) codes of ethics, 2) preparing triple bottom line reports (social, environmental, and financial), and 3) launching public relations campaigns, that support and define socially responsible corporate behavior ([12], p. 550). These aspects of CSR naturally changed ethics and generate the creation of corporate citizenship influencing overall corporate value, through benefits seen in financial performance (profitability, growth, and operating efficiency), and reduced costs of capital by means of adhering to corporate ethical practices [13] [14]. In the 1980s, a growing interest in social issues emerged leading scholars to deal more and more with corporate social performance [15]. This trend has been gradually extended to all countries in the 1990s [16]. Several surveys acknowledged this increasing attention to social issues in supply chain management. Zorzini et al. [17] provided an interesting review of socially responsible sourcing by suggesting some theoretical developments on this topic while Reefke and Sundaram [18] reviewed the literature dealing with sustainable practices by using content analysis (developed in Delphi). Finally, let us mention Feng et al. [19] who provided a network analysis of the literature indicating the growing interest for CSR issues in SCM literature.

Although many managers acknowledge the importance of the sustainable dimension in the supply chain management, they are not always able to clearly identify the positive influence of such management. A 1999 survey made by Price Waterhouse Coopers (PWC) in more than 25 countries showed that the notion of sustainability is mainly associated with the brand and the reputation of companies. However, the implementation of a sustainable supply chain can also improve the financial situation of the company. This article aims, firstly, at mapping the importance of this notion in the literature dealing with industry and, secondly, at suggesting an economic reasoning justifying the integration of this notion in the supply chain management.

\section{Methodology}

To map the importance of the works dealing CSR practices, we used a systematic review. Generally speaking, such approach can be defined as "a specific methodology that locates existing studies selection and contribution, analysis and synthesizes data, and reports the evidence in such a way that allows reasonable clear conclusions to be reached about what is and is not known" [20] [21] [22]. Following this definition and rationale, we use the systematic review as a specific 
methodology to collect data about the theme of CSR. In other words, this article does not provide a literature review on CSR (i.e. a holistic narration about how CSR is dealt in the existing literature)-this paper rather uses a systematic review to obtain raw observation on the occurrence of CSR in the literature. Our methodology follows a six-stage classification approach to examine the importance of corporate social responsibility (CSR) in supply chain management literature.

In a first step, we identify an initial data point (2006) was based on the first paper related to CSR and supply chain which surfaced as a result of our search. The conference proceeding, thesis, work in progress, and technical reports were all excluded from our research to ensure a high quality of acceptable and valid articles [23] [24]. Afterwards, we limited our literature search to English academic peer-reviewed journals including EBSCO Host, Google Scholar, and ProQuest to confirm complete coverage of the structured search terms including "corporate social responsibility", "corporate citizenship", and "supply chain". Complete bibliographic details of all reviewed articles are included in the Appendix to validate the clarity and transparency of the research (Table 1).

Table 1. Criteria for article selection.

\begin{tabular}{cc}
\hline $\begin{array}{c}\text { Step } 2 \& 3 \\
\text { Criteria selection }\end{array}$ & Description \\
Keywords & $\begin{array}{c}\text { Corporate social responsibility, } \\
\text { corporate citizenship, supply Chain }\end{array}$ \\
Language \& & English peer-reviewed \\
document type & academic journals \\
Time & $2006-2016$ \\
interval &
\end{tabular}

In the third step, the collection of articles has been reviewed over a decade beginning in 2006, from 7 of the foremost germane databases including: Emerald, Science Direct, Sage, Wiley, Jstor, EBSCO, and Taylor \& Francis. At this state, the authors carefully reviewed and critically evaluated all data in the title, abstract, and body of text to ensure the relevancy and validity of all of the selected papers.

Stage 4: In a fourth step, we selected this systematic review to structure our research resources. Precisely articles were categorized by: 1) journal wise publication, 2) year of publication, 3) geographic location, 4), industry, and 5) authors, including a total of 116 articles published in seven key databases.

The fifth step mapped the importance of CSR in the literature to appreciate the current trends and future research bearings while our final step was to suggest a conceptual framework formalizing economic reasoning that might explain the trend we observe in empirical data. Our methodology can be summarized as follows (Figure 1). 


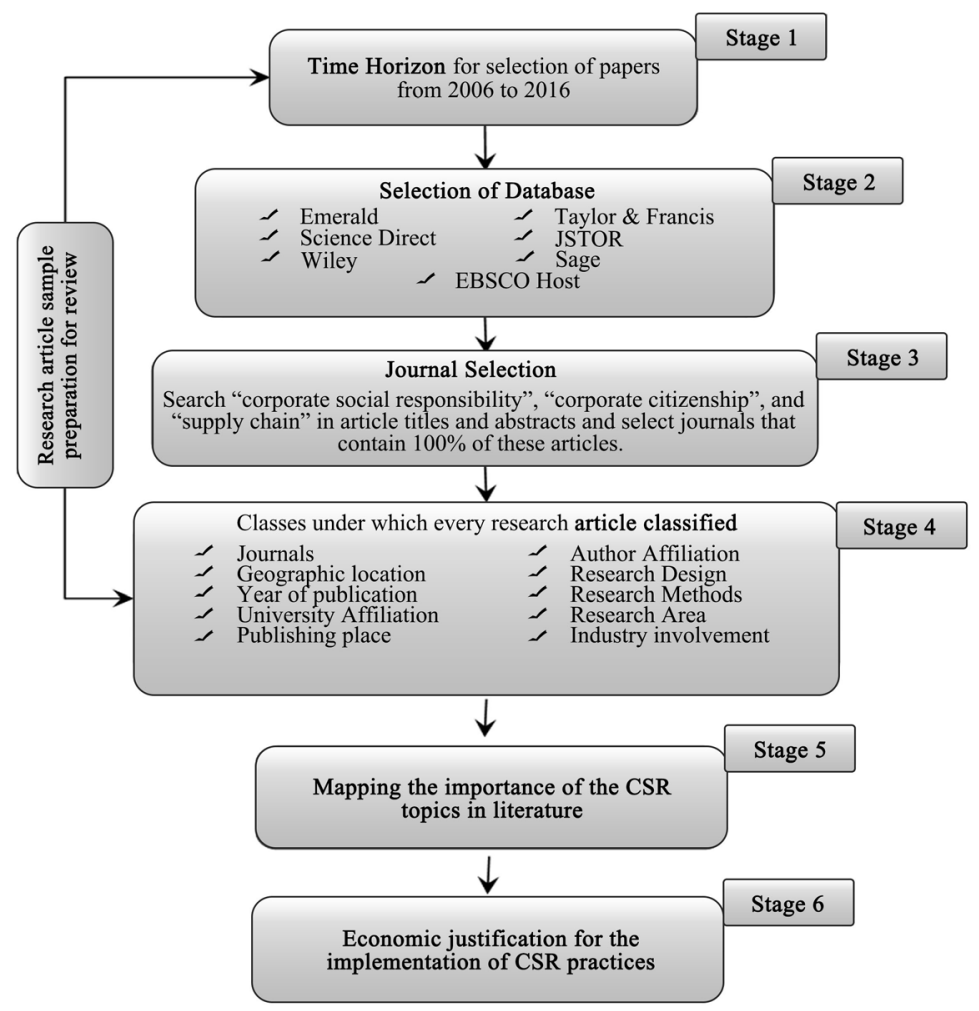

Figure 1. Structured Literature Review Methodology. Source: Adapted from Akbari [23], Seuring and Muller [25], Soni and Kodali [26], Malviya and Kant [27] and Winter and Knemeyer [28].

Such a bibliometric approach can handle data related to publications to construct a solid empirical methodology. Our major objective is not to provide a literature review but rather to identify and map the increasing of body of knowledge related to CSR issues in SCM by using an alternative methodology than those used by the previous surveys on the topic. Let us present our data analysis in the following section.

\section{Data Presentation}

In terms of journals, it is worth mentioning that that Supply Chain Management: An International Journal published the greatest number of papers (11). This is followed by Social Responsibility Journal International (7), Journal of Production Economics (6), Production and Operations Management, and Journal of Business Ethics (5 each), Journal of Cleaner Product, and Dynamic Factor Models (4 each), British Food Journal, and Corporate Governance: The International Journal of Business in Society (3 each), European Journal of Operational Research, Journal of Supply Chain Management, Business Strategy and the Environment, International Journal of Contemporary Hospitality, International Journal of Operation \& Production Management, Corporate Governance, Public Relations Review, International Journal of Sociology and Social Policy, and Journal of Management Development (2 each). The table hereafter summarizes our data on this aspect. 


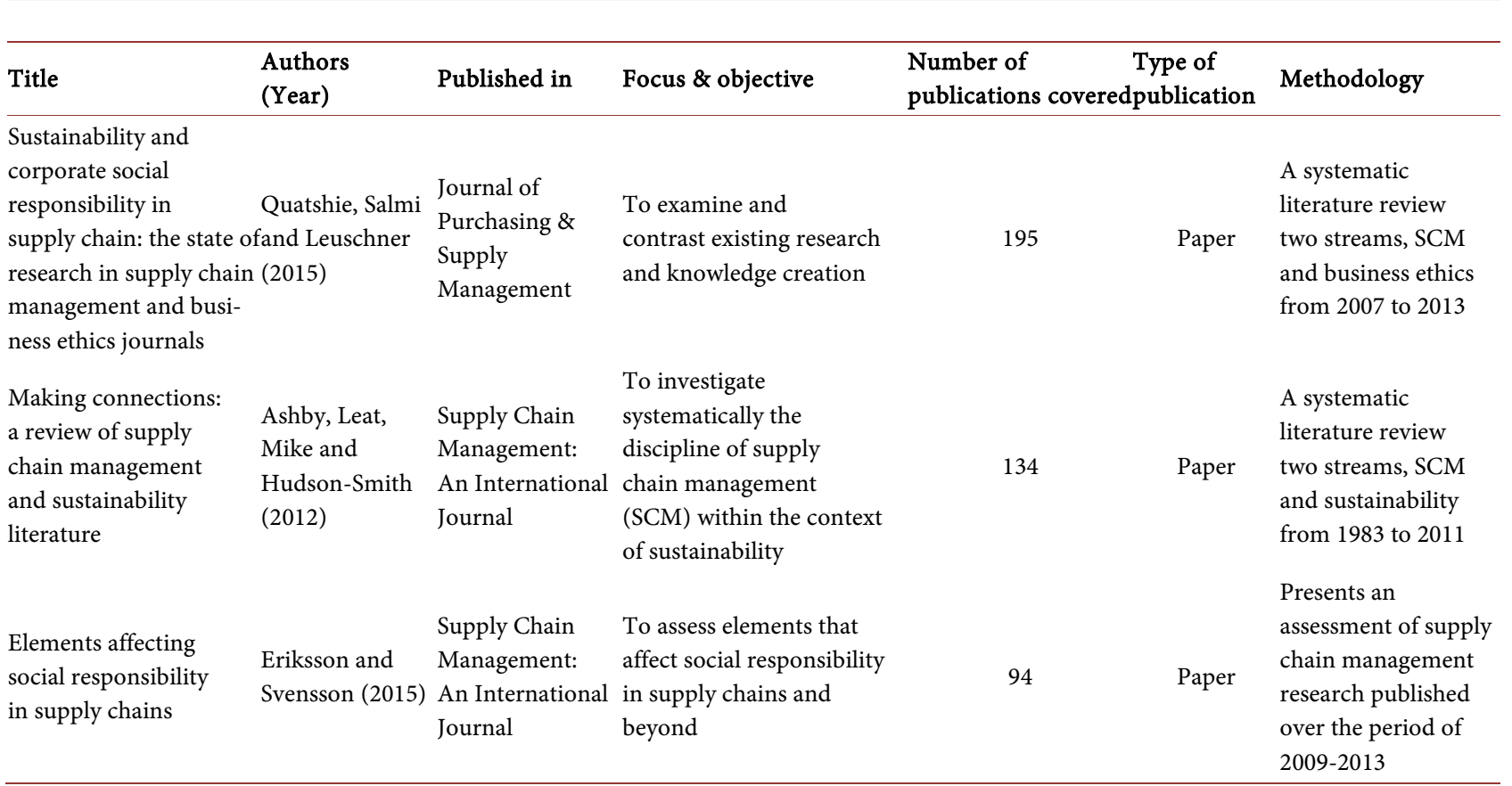

The remaining 33 journals published one paper each. This classification highlights key journals contributing to the literature devoting to CSR. Such literature is of course important since it also supports practitioners and researchers in the discipline area of sustainable supply chain development.

A timeline analysis of the 116 published articles is represented in Figure 2. The data reflects overall long-term growth, with peaks in number of publications, after 2010, followed by constant valleys as to number of publications each following year. The overall trend supports interest and awareness by researchers of CSR, and sustainable supply chain development. This validates an increased attentiveness and pursuit amongst current and future researchers into the area of sustainable supply chain management. As mentioned by Malviya and Kant [27] an increased global pervasiveness of advancing technology, specifically, the internet, which plays a significant role in the overall increasing trend in articles between 2006 and 2016. However, a dramatic decrease in publications in 2011 and 2014 is with a still unclear reason.

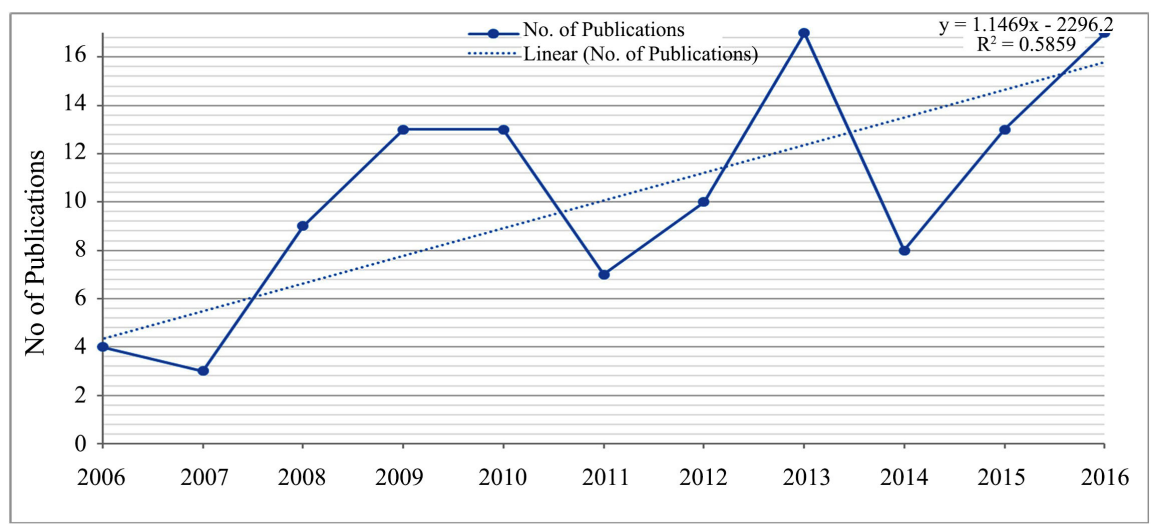

Figure 2. Evolution of our data in year by year. 
Although the cyclical evolution of the number of papers devoted to CSR, one can clearly observe an increasing trend indicating the growing importance of this topic in logistics and supply chain management. These results confirm the existing surveys on the topic [17] [19].

Beyond this increasing trend, we also questioned the kind of publications, we therefore investigated this aspect in the data. In this perspective, a comprehensive analysis and examination of each article found that all the research articles focused on surveys, interviews, mathematical and conceptual modelling, case study and simulations. A considerable number of published papers focused on conceptual model (36), followed by articles focusing on survey (35), mathematical modelling and case study (17 each), interviews (5), and case study and mathematics with four, and survey and interviews in only two articles (Figure 3).

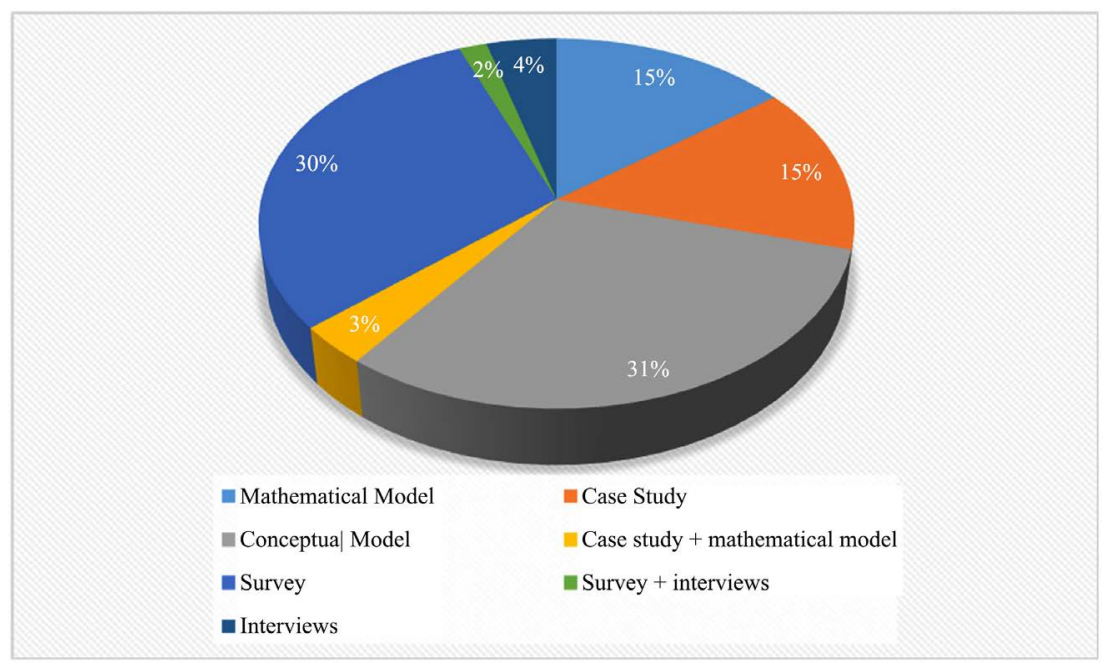

Figure 3. Research methods identified in articles dealing with CSR topics.

The importance of conceptual (and mathematics) models indicates that the field of CSR in SCM is still in its early stage and that no dominant framework is actually ruling the literature. This observation is common in history of science: when a field is in its infancy, there is no dominant mainstream to define an implicit common knowledge shared by scholars [29]. A new field appears therefore as an open-space for new ideas and methods explaining the proliferation of conceptual articles focusing on the crystallization and fixation of academic conventions. In such period, scholars mainly work on conceptual models to contribute to the sedimentation of a new area of knowledge [30]. This observation usually goes hand in hand with the fact that empirical studies are quite limited in the field. Indeed, empirical studies usually refer to a contextualization of a specific conceptual model. With no conceptual framework dominating the way CSR issues are perceived/implemented in SCM, the number of empirical studies is necessary limited.

The consideration of CSR in sustainable supply chain analyses by country generates a cognizance between practitioners and researchers vis-à-vis the intensity 
of attention in different geographical locations. Figure 4 shows the country distribution across the 116 published papers, encompassing 24 countries around the world.

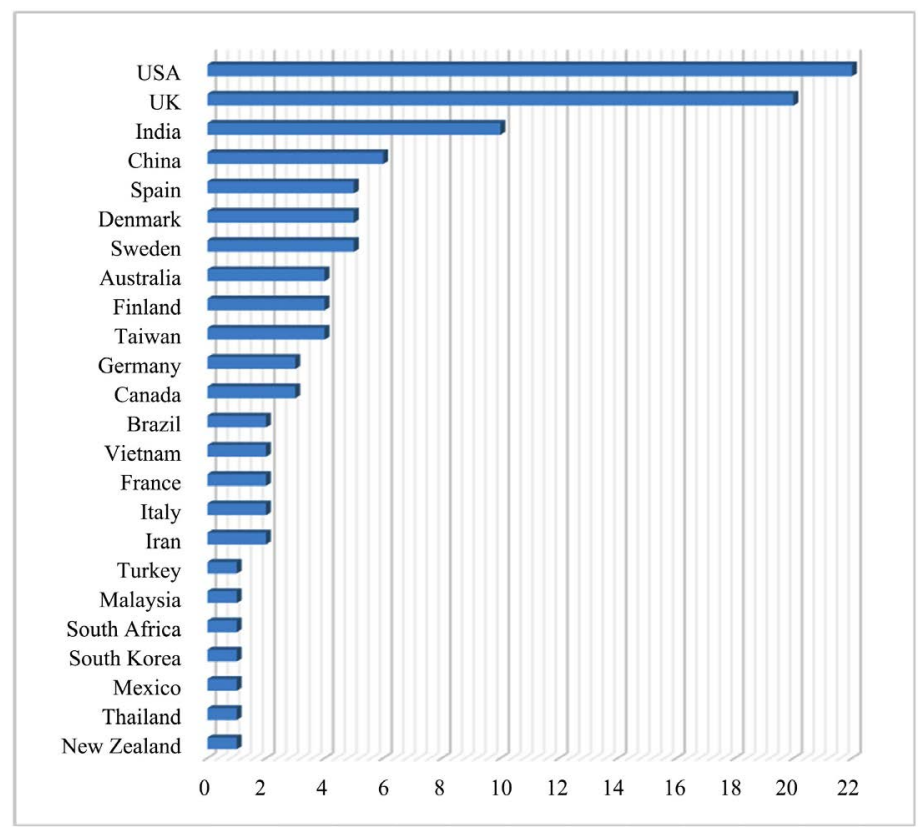

Figure 4. Classification of articles based on country.

Figure 4 indicates that out of 116 published papers/articles and authors, the USA contributed the most number of publications (31), followed by the United Kingdom (20). Apart from the USA and the UK, various countries such as India, China, Spain, Denmark, Finland, Sweden, Australia, Finland, and Taiwan are also participating countries addressing CSR in sustainable supply chain. These numbers give another perspective on the existing works [17] [19] on the topics. Precisely, in their study, Feng et al. [19] mentioned Netherlands as the third country contributing to the CSR literature in SCM while India was not in the top 8 of these countries. In our data, Netherlands is not in the list and India appears to be the third country contributing to this literature. Two methodological reasons can explain these differences: 1) Feng et al. [19] used a larger database (Scopus) that might eventually capture articles from Netherlands, and 2) Feng et al. [19] also integrate the terms "ISO 26000" and "SA 8000" as keywords in their analysis; these labels referring to international standards for evaluation of CSR practices.

Expect these differences, our findings confirm the existing observations made by previous works on the topics. Carter and Jennings [31] surveyed 201 companies regarding CSR and supply chain relationships showing the importance of this concept in this country. Tiwari, Turner, and Younis [32] expanded their investigation to present a guide for purchasing specialists to assess the CSR influence on procurement decisions in a UK automotive manufacturer. Shukla, Deshmukh and Kanda [33] surveyed the Indian automotive sector to identify 
levels of implementation, reasons, practices and performance of environmental and social consciousness of supply chain management related to CSR. Germany, Canada, Brazil, Vietnam, France, Italy, Iran, Turkey, Malaysia, South Africa, South Korea, Mexico, Thailand, and New Zealand, are characterized as countries where the number of research publications on logistics outsourcing is quite low (but existing).

The published articles have also been classified by industry into different categories. The category of "General" (cross-industry analysis) was the most published group (32 percent) in comparison with other industries focusing on sustainable supply chain practices. This level of generalization is actually in line with our observations evoked earlier. Because CSR in SCM is still in its infancy, there is no dominant framework that can be contextualized in different industries but rather a collection of generalist works dealing with industry at large. Corresponding to the reviewed literature, the next most prominent industry was manufacturing (19 percent), followed by food and beverage ( 9 percent) and then services (8 percent) (Figure 5$)$. Other industry sectors researched included e-commerce, electronics, agriculture \& agribusiness, apparel \& accessories, sports, construction, tourism, public relations, chemical, consulting, health and pharmaceutical. The low number of articles devoted to CSR practices in the pharmaceutical industry is quite surprising given the fact that this industry directly deals with impact on human health making CSR important.

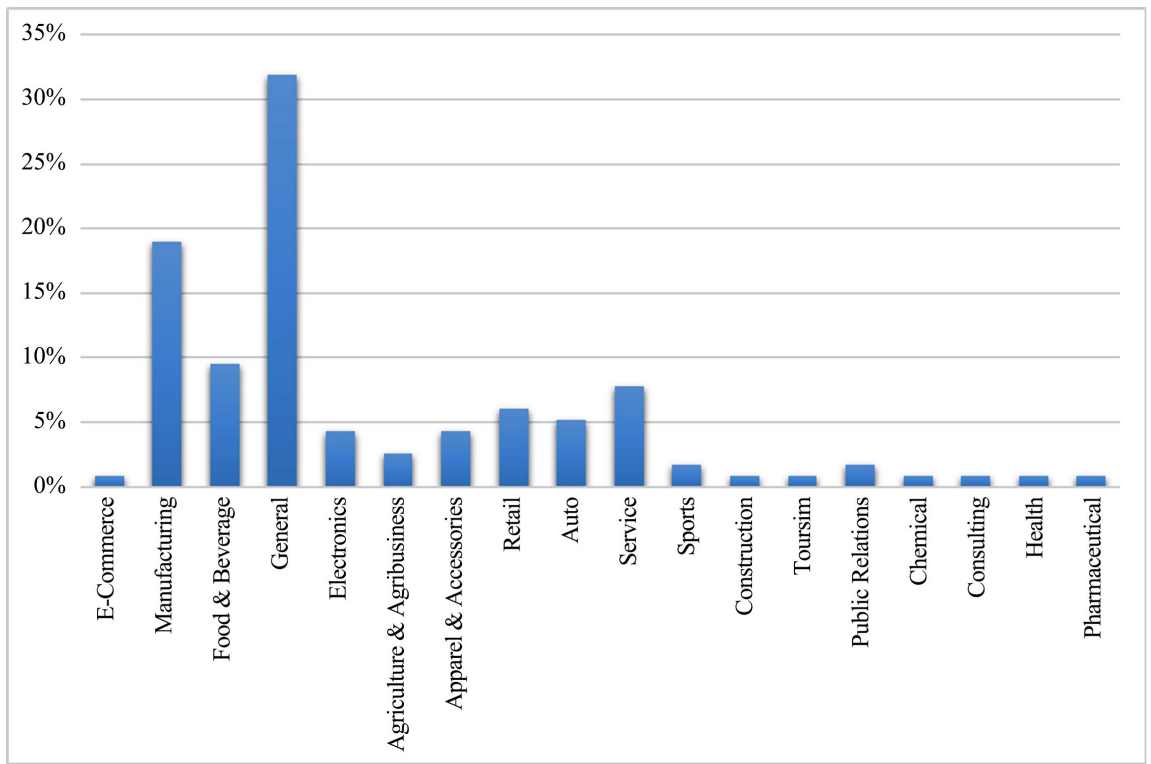

Figure 5. Classification of publications based on industry.

This section offered empirical evidences indicating the growing importance of the CSR issues in the existing literature. This observation has been emphasized at different levels (theoretical, geographical and industry level). As evoked earlier, CSR in SCM is still in its early stages and the majority of works focused on conceptual analysis for a potential cross-industrial application. In the following 
section, we partly contribute to this trend by suggesting a conceptual frame justifying, from an economic point of view, the observed increasing interest in CSR in SCM field.

\section{Economic Justification of the Increasing Interest in Sustainable Supply Chain Management}

Of course, the growing interest in CSR issues in SCM did not come by chance. Many moral/social aspects can explain this popularity [34]. In this section, we introduce a complementary justification by offering a conceptual framework formalizing the economic reason for which we observe a growing interest in CSR issues in SCM. Sustainable supply chain management is expected to increase the value of the companies through different aspects [35]. This section aims at reviewing these aspects by providing an economic reasoning to their implementation.

There are many aspects that can justify the implementation of a sustainable supply chain: increase the customers' favorable response and the stakeholders's satisfaction, higher sales, employees's behaviors etc. (see Mefford [36] for a detailed analysis of these dimensions). Generally speaking the influence of sustainable supply chain practices can improve two different processes in the enterprise: the production and the financial chains. Figure 6 illustrates the influence of appropriate supply chain practices on the production.

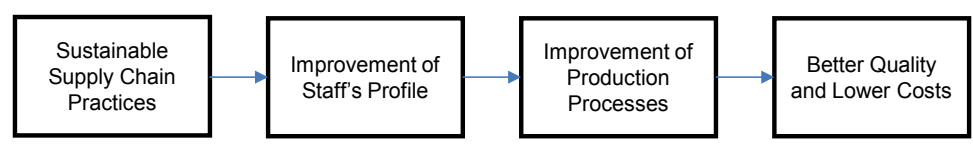

Figure 6. Sustainable supply chain effects on production.

In the same vein, the implementation of sustainable practices is usually combined with the recognition of employees as an asset for the company. In this context, skills, profiles and motivations of employees lead to an improvement of production processes. This improvement leads to an increase in the quality of the production at lower costs meaning that, potentially, one can expect an increase in the profits and therefore a higher stock price for companies that are quoted. This influence can be schematized as follows (Figure 7).

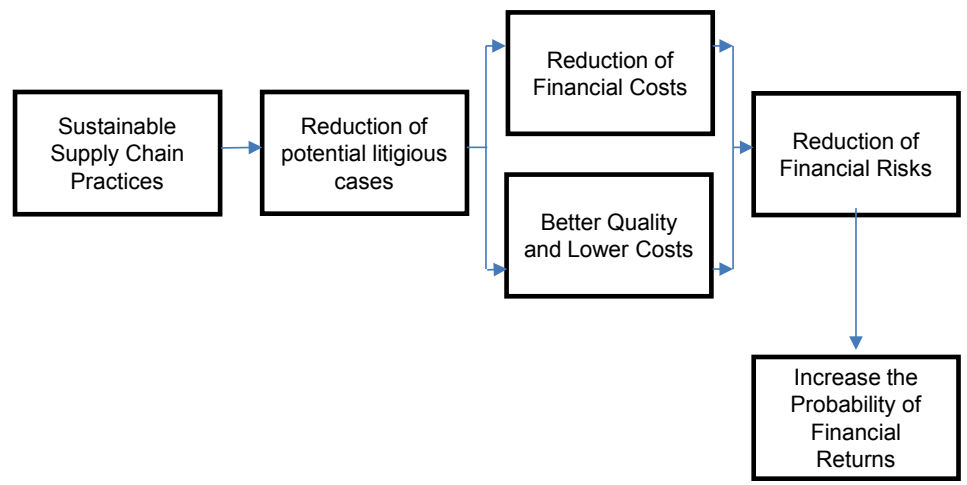

Figure 7. Sustainable practices and their influence on the financial value of the firm. 
Benefits from sustainable practices in supply chain can take different forms: a reduction of the financial risk (and therefore cost) related to corporate social responsibility and better quality. Concretely, such practices reduce the risk of litigious cases between the company and its environment decreasing therefore the likelihood of lawsuits-stakeholders are less likely to sue the company if they consider it is ethical in its practices. In the same vein, a fair/good treatment of employees in the supply chain management also decrease the risk of legal actions coming from employees. The reduced possibility to face with costly litigious case contributes to the reduction of uncertainty increasing therefore the predictability of future cash flows. These aspects have been quantified in the literature where Alexander and Buccholz [35], Donean and Oanea [37] or Wang [38], for instance, showed that CSR activities have a significant positive influence on the financial returns. Von Arx and Ziegler [39], or Maqbool and Zameer [40] also detailed such effect by emphasizing the econometric positive effect of CSR activities on the dynamics of financial prices. Statistically speaking, these studies showed that sustainable chain practices can actually affect the statistical distribution describing to the evolution of financial prices. In this perspective, one could expect that, in case of success of the implementation, these practices make the distribution related to financial returns more skewed on the left by reducing the "bad variance".

Interestingly, despite the collection of empirical studies testifying the positive influence of the CSR practices on the dynamics of financial prices, there is no framework unifying these observations. This is the objective of this section since we suggest a conceptual framework justifying these observations and formalizing the reason why CSR appear to be increasingly important in the existing literature. As mentioned earlier, the valuation of the potential outcome of sustainable practices in supply chain management depends on a distortion of existing data meaning that first step in this estimation is to identify an appropriate technique transforming existing data. Among the variety of existing statistical transformations, a classical case is the one proposed by Fleishman [41] in which the transformed variable (financial return after the implementation of CSR practices) will take the form $Y=a+b X+c X^{2}+d X^{3}$ where $X$ is the distributed variable (initial distribution of the financial returns before the implementation of CSR practices). The constants $a, b, c$, and $d$ are chosen such that $Y$ has a distribution in line with the target parameters. In the same vein, if we know that a successful sustainable practice has a left skewed impact on the initial distribution of the financial return; one can expect to have the following condition for the third moment:

$$
E\left[\frac{Y-\mu_{C S R}}{\sigma_{C S R}}\right]<E\left[\frac{X-\mu_{0}}{\sigma_{0}}\right]
$$

where $Y$ is the transformed financial returns, $\mu_{C S R}$ and $\sigma_{C S R}$ is respectively be the mean and the variance of this transformed rate while $X$ refers to initial (non-transformed) financial returns with their mean $\left(\mu_{0}\right)$ and their variance $\left(\left(\sigma_{0}\right)\right)$. 
After having identified the kind of transformation the original distribution of financial returns has in case of implementation of sustainable practices, the second step (2) related to this valuation refers to the integration of uncertainty associated with the company's cash flows. Indeed, the incomplete nature of the markets combined with the complexity of economic environment necessitates an estimation of uncertainty which can be valued through an entropy measure (this approach is common in what econometricians call "info-metrics" which refers to a practice offering a "mathematical foundation for inference with incomplete information" ([42], p. 3). The major idea behind this entropic measure is to associate uncertainty with a variational relationship between the original distribution and the transformed ones [43]. Since a transformed distribution can be derived from the initial one through a statistical transformation, further investigations in this entropic measure of uncertainty should be done in the future [44]. Although several research pathways can be investigated, a potential perspective can associate this uncertainty with what actuaries call the Wang transformation which is a distortion technique transforming one probability measure to another one by integrating a risk aversion or a risk premium parameter $(\lambda)$. The Wang transformation takes the following general form,

$$
F^{*}(x)=\phi\left[\phi^{-1}(F(x))+\lambda\right]
$$

where $\phi$ is the cumulative distribution of the normal standard distribution (the form of this function can easily be estimated by statistical software). In our perspective, this distribution is the transformed distribution ${ }^{1}$,

$$
F^{*}(x)=\phi\left[\phi^{-1}\left(F\left(\mu_{C S R}, \sigma_{C S R}\right)\right)+\lambda\right]
$$

where $\lambda \geq 0$ is the risk aversion parameter which can be derived from a classical risk-premium perspective ${ }^{2} . F\left(\mu_{C S R}, \sigma_{C S R}\right)$ can be associated with the statistical distribution describing the dynamics of financial returns after the implementation of sustainable practices.

Although managers are usually aware of the positive influence of CSR practices on the financial value of the companies and even though empirical studies showed such positive link, this relationship is sometime embedded in the global activity of the firms. This section offered an economic justification in the increasing popularity of CSR issues observed in SCM literature. Precisely, we clarified this aspect by providing a conceptual formalization of such influence. Our reasoning justifying the implementation of CSR practices can partly explain the growing interest in this topic that we identified in the first part of this paper.

\section{Conclusions}

From our data analysis conducting 116 articles collected from 7 publishers' da-

${ }^{1}$ Wang [43] showed that Wang transformation can also be used with skewed distribution.

${ }^{2}$ The estimation of this parameter can take different forms depending on the way of characterising the risk. For example, one can use a mere difference between the expected return given for the company and the risk-free rate $E[R]-r$. 
tabase between 2006 and 2016, it appears that CSR topics are increasingly investigated by scholars in logistics and supply chain management. This importance has been observed at different levels: theoretically and geographically, and industrially speaking, we can observe a growing trend in the literature. Our findings indicate that CSR issues in SCM, as a research topic, are still in their early stage with no real dominant framework (but numerous of conceptual papers) and a lack of empirical studies. This appears as a potential gap in the existing literature where more practical/quantitative research can be anticipated. Another interesting conclusion: our bibliometric analysis shows that CSR issues in SCM are more and more studied in emerging countries (India, China, Vietnam, Brazil etc.) while previous surveys on the topic emphasized the lack of research in these countries. It appears from our data that this gap is gradually filled by scholars in the field.

Beyond this bibliometric analysis, our paper aimed at offering a justification for this growing interest in CSR issues in SCM. There are many moral and societal aspects that can explain this interest and a lot of empirical works testify the positive relationship between CSR practices and the dynamics of financial practices. However, despite these collections of studies, there is no formal framework unifying the increasing importance of CSR in supply chain management. This article is a first attempt in this direction and further research will be developed by the authors.

\section{Conflicts of Interest}

The authors declare no conflicts of interest regarding the publication of this paper.

\section{References}

[1] United Nations (2007) What Is CSR? United Nations Industrial Development Organization. http://www.unido.org/csr/o72054.html

[2] Christopher, M. (2016) Logistics and Supply Chain Management. 5th Edition, Pearson, London.

[3] Chopra, S. and Meindl, P. (2015) Supply Chain Management: Strategy, Planning, and Operation. 6th Edition, Pearson, London.

[4] Prokesch, S. (2010) The Sustainable Supply Chain. Harvard Business Review. https://hbr.org/2010/10/the-sustainable-supply-chain

[5] Cohen, S. and Roussel, J. (2013) Strategic Supply Chain Management: The Five Core Disciplines for Top Performance. 2nd Edition, McGraw-Hill, New York.

[6] Greenstein, S. (2014) Sustainability Starts with Supply Chain. Industry Week, Advancing the Business of Manufacturing. http://www.industryweek.com/supplier-relationships/sustainability-starts-supply-c hain

[7] Dyllick, T. and Hockerts, K. (2002) Beyond the Business Case for Corporate Sustainability. Business Strategy and the Environment, 11, 130-141. https://doi.org/10.1002/bse.323

[8] Kolpin, D.W., Furlong, E.T., Meyer, M.T., Thurman, E.M., Zaugg, S.D., Barber, L.B. 
and Buxton, H.T. (2002) Pharmaceuticals, Hormones, and Other Organic Wastewater Contaminants in U.S. Streams, 1999-2000: A National Reconnaissance. Environmental Science \& Technology, 36, 1202-1211.

https://doi.org/10.1021/es011055j

[9] Andresen, M. and Skjoett-Larsen, T. (2009) Corporate Social Responsibility in Global Supply Chains. Supply Chain Management: An International Journal, 14, 75-86. https://doi.org/10.1108/13598540910941948

[10] Friedman, M. (1970) The Social Responsibility of Business Is to Increase Its Profits. New York Time Magazine, 13, 32-33.

[11] Pintea, M.O. (2015) The Relationship between Corporate Governance and Corporate Social Responsibility. Review of Economic Studies \& Research Virgil Madgearu, 8, 91-108.

[12] Weaver, G., Trevino, L. and Cochran, P. (1999) Integrated and Decoupled Corporate Social Performance: Manager Commitments, External Pressures, and Corporate Ethics Practices. Academy of Management Journal, 42, 539-552. https://doi.org/10.2307/256975

[13] Blazovich, J.L. and Smith, L.M. (2011) Ethical Corporate Citizenship: Does It Pay? Research on Professional Responsibility and Ethics in Accounting, 127-163. https://doi.org/10.1108/S1574-0765(2011)0000015008

[14] [Kot, S. (2014) Knowledge and Understanding of Corporate Social Responsibility. Journal of Advanced Research in Law and Economics, 5, 109-119.

[15] Carroll, A. (1979) A Three-Dimensional Conceptual Model of Corporate Performance. Academy Management Review, 4, 497-505. https://doi.org/10.5465/amr.1979.4498296

[16] John, E. (1997) Cannibals with Forks: The Triple Bottom Line of the 21st Century Business. Capstone Publishing Ltd., Oxford.

[17] Zorzini, M., Hendry, L., Huq, F. and Stevenson, M. (2015) Socially Responsible Sourcing: Reviewing the Literature and Its Use of Theory. Journal of Operation Production Management, 35, 60-109. https://doi.org/10.1108/IJOPM-07-2013-0355

[18] Reefke, H. and Sundaram, D. (2017) Key Themes and Research Opportunities in Sustainable Supply Chain Management-Identification and Evaluation. Omega: The International Journal of Management Science, 66, 195-211. https://doi.org/10.1016/j.omega.2016.02.003

[19] Feng, Y., Zhu, Q. and Lai, K.-H. (2017) Corporate Social Responsibility for Supply Chain Management: A Literature Review and Bibliometric Analysis. Journal of Cleaner Production, 158, 296-307. https://doi.org/10.1016/j.jclepro.2017.05.018

[20] Denyer, D. and Tranfield, D. (2009) Chapter 39 Producing a Systematic Review. In: Buchanan, D. and Bryman, A., Eds., The Sage Handbook of Organizational Research Methods, Editors Sage Publications Ltd., London, 671-689.

[21] Jafari, H. (2015) Logistics Flexibility: A Systematic Literature Review. International Journal of Productivity and Performance Management, 64, 947-970. https://doi.org/10.1108/IJPPM-05-2014-0069

[22] Transfield, D., Denyer, D. and Smart, P. (2003) Towards a Methodology for Developing Evidence-Informed Management Knowledge by Mean of Systematic Review. British Journal of Management, 14, 207-222. https://doi.org/10.1111/1467-8551.00375

[23] Akbari, M. (2018) Logistics Outsourcing: A Structured Literature Review. Benchmarking. An International Journal, 25, 1548-1580. https://doi.org/10.1108/BIJ-04-2017-0066 
[24] Touboulic, A. and Walker, H. (2015) Theories in Sustainable Supply Chain Management: A Structured Literature Review. International Journal of Physical Distribution and Logistics Management, 45, 16-42. https://doi.org/10.1108/IJPDLM-05-2013-0106

[25] Seuring, S. and Muller, M. (2008) From Literature Review to a Conceptual Framework for Sustainable Supply Chain Management. Journal of Cleaner Production, 16, 1699-1710. https://doi.org/10.1016/j.jclepro.2008.04.020

[26] Soni, G. and Kodali, R. (2011) A Critical Analysis of Supply Chain Management Content in Empirical Research. Business Process Management Journal, 17, 238-266. https://doi.org/10.1108/14637151111122338

[27] Malaviya, R.K. and Kant, R. (2015) Green Supply Chain Management (GSCM): A Structured Literature Review and Research Implications. Benchmarking: An International Journal, 22, 1360-1394. https://doi.org/10.1108/BIJ-01-2014-0001

[28] Winter, M. and Knemeyer, A.M. (2013) Exploring the Integration of Sustainability and Supply Chain Management: Current State and Opportunities for Future Inquiry. International Journal of Physical Distribution and Logistics Management, 43, 18-38. https://doi.org/10.1108/09600031311293237

[29] Schinckus, C. (2018) When Physicists Become Undisciplined: Essay on Econophysics. PhD Dissertation in History and Philosophy of Science, University of Cambridge, Cambridge.

[30] Byron, K. and Khazanchi, S. (2012) Reward and Creative Performance: A Meta-Analytic Test of Theoretically Derived Hypotheses. Psychological Bulletin, 138, 809-830. https://doi.org/10.1037/a0027652

[31] Carter, C.R. and Jennings, M.M. (2002) Social Responsibility and Supply Chain Relationships. Transportation Research Part E, 38, 37-52. https://doi.org/10.1016/S1366-5545(01)00008-4

[32] Tiwari, A., Turner, C. and Younis, K. (2014) Socially Responsible Purchasing in the Automotive Industry. Social Responsibility Journal, 10, 620-645. https://doi.org/10.1108/SRJ-05-2012-0056

[33] Shukla, A.C., Deshmukh, S.G. and Kanda, A. (2009) Environmentally Responsive Supply Chains Learnings from the Indian Auto Sector. Journal of Advances in Management Research, 6, 154-171. https://doi.org/10.1108/09727980911007181

[34] Amaeshi, K., Osuji, O. and Nnodim, P. (2008) Corporate Social Responsibility in Supply Chains of Global Brands: A Boundaryless Responsibility? Clarifications, Exceptions and Implications. Journal of Business Ethics, 81, 223-234. https://doi.org/10.1007/s10551-007-9490-5

[35] Alexander, G. and Buchholz, R. (1978) Corporate Social Responsibility and Stock Market Performance. The Academy of Management Journal, 21, 479-486. https://doi.org/10.5465/255728

[36] Mefford, R. (2011) The Economic Value of Sustainable Supply Chain. Business and Society Review, 16, 109-143.

[37] Donean, A. and Oanea, D. (2017) CSR and Company's Stock Price-A Comparative Evidence from Bucharest Stock Exchange. EuroEconomica, 36, 2-13.

[38] Wang, G. (2011) Corporate Social Responsibility and Stock Performance-Evidence from Taiwan. Modern Economy, 2011, 788-799.

[39] Von Arx, U. and Ziegler, A. (2014) The Effect of Corporate Social Responsibility on Stock Performance: New Evidence for the USA and Europe. Quantitative Finance, 14, 977-991. https://doi.org/10.1080/14697688.2013.815796 
[40] Maqbool, S. and Zameer, N. (2018) Corporate Social Responsibility and Financial Performance: An Empirical Analysis of Indian Banks. Future Business Journal, 4, 84-93. https://doi.org/10.1016/j.fbj.2017.12.002

[41] Fleishman, A.I. (1978) A Method for Simulating Non-Normal Distributions. Psychometrika, 43, 521-532. https://doi.org/10.1007/BF02293811

[42] Golan, A. (2013) On the State of the Art of Info-Metrics. In: Van-Nam Huynh, K.V., Sriboonchitta, S. and Suriya, K., Eds., Uncertainty Analysis in Econometrics with Applications Advances in Intelligent Systems and Computing, Springer, Berlin, Vol. 200, 3-15. https://doi.org/10.1007/978-3-642-35443-4_1

[43] Wang, S. (1996) Premium Calculation by Transforming the Layer Premium Density. ASTIN Bulletin, 26, 71-92. https://doi.org/10.2143/AST.26.1.563234

[44] Li, B., Wang, T. and Tian, W. (2013) Risk Measures and Asset Pricing Models with New Versions of Wang Transform. In: Van-Nam Huynh, K.V., Sriboonchitta, S. and Suriya, K., Eds., Uncertainty Analysis in Econometrics with Applications Advances in Intelligent Systems and Computing, Springer, Berlin, Vol. 200, 155-171. 


\section{Appendix}

\section{Papers Reviewed}

Adebanjo, D., Ojadi, F., Laosirihongthong, T., \& Tickle, M. (2013). A case study of supplier selection in developing economies: a perspective on institutional theory and corporate social responsibility. Supply Chain Management: An International Journal, 18(5), 553-566. https://doi.org/10.1108/SCM-08-2012-0272

Airike, P., Rotter, J. P., \& Mark-herbert, C. (2016). Corporate motives for multi-stakeholder collaboration e corporate social responsibility in the electronics supply chains. Journal of Cleaner Production, 131, 639-648. https://doi.org/10.1016/j.jclepro.2016.04.121

Alt, E., \&Spitzeck H. (2016). Improving environmental performance through unit-level organizational citizenship behaviors for the environment: A capability perspective. Journal of Environmental Management, 182, 48-58. https://doi.org/10.1016/j.jenvman.2016.07.034

Amaeshi, K.M., Osuji, O.K., Nnodim, P., (2007). Corporate Social Responsibility in Supply Chains of Global Brands: A Boundaryless Responsibility? Clarifications, Exceptions and Implications. Journal of Business Ethics, 81(1), 223-234.

Andersen, M., \&Skjoett-Larsen, T. (2009). Corporate social responsibility in global supply chains. International Journal of Life Cycle Assessment, 14(2), 75-86. https://doi.org/10.1108/13598540910941948

Anner, M. (2012). Corporate Social Responsibility and Freedom of Association Rights: The Precarious Quest for Legitimacy and Control in Global Supply Chains. Politics and Society. https://doi.org/10.1177/0032329212460983

Armitage, A., \& Keeble-Allen, D. (2008). Undertaking a Structured Literature Review or Structuring a Literature Review: Tales from the Field. The Electronic Journal of Business Research Methods, 6(2), 103-114.

Arya, A., \&Mittendorf, B. (2015). Supply Chain Consequences of Subsidies for Corporate Social Responsibility. Production and Operations Management, 24(8), 1346-1357. https://doi.org/10.1111/poms.12326

Ashby, A., Leat, M., \& Hudson-Smith, M. (2012). Making connections: A review of supply chain management and sustainability literature. Supply Chain Management, 17(5), 497-516. https://doi.org/10.1108/13598541211258573

Asifsalam, M. (2009). Corporate Social Responsibility in Purchasing and Supply Chain. Journal of Business Ethics, 85, 355-370.

Awaysheh, A., \& Klassen, R.D. (2010). The impact of supply chain structure on the use of supplier socially responsible practices. International Journal of Operation \& Production Management, 30. https://doi.org/10.1108/01443571011094253

Ayuso, S., Roca, M., \&Colome, R. (2013). SMEs as "transmitters" of CSR requirements in the supply chain. Supply Chain Management: An International Journal, 18(5), 497-508. https://doi.org/10.1108/SCM-04-2012-0152

Bair, J., \&Palpacuer, F. (2015). CSR beyond the corporation: contested governance in global value chains. Global Networks, 15(1), 1-19. https://doi.org/10.1111/glob.12085

Bartikowski, B., \& Walsh, G. (2011). Investigating mediators between corporate reputation and customer citizenship behaviors. Journal of Business Research, 64(1), 39-44. https://doi.org/10.1016/j.jbusres.2009.09.018

Becker, W. S., Ii, J. A. C., \&Langella, I. M. (2010). Beyond Self-Interest: Integrating Social Responsibility and Supply Chain Management With Human Resource Development, Human Resource Development Review, 9(2), 144-168. 
https://doi.org/10.1177/1534484309357877

Bhardwaj, B.R. (2016). Role of green policy on sustainable supply chain management: a model for implementing corporate social responsibility (CSR). Benchmarking: An International Journal, 23(2), 456-468. https://doi.org/10.1108/BIJ-08-2013-0077

Birch, D., (2008). Ten principles of corporate citizenship. Social Responsibility Journal, 4(1/2), 129-135. https://doi.org/10.1108/17471110810856893

Bisogno, M. (2016). Corporate social responsibility and supply chains: contribution to the sustainability of well-being. Agriculture and Agricultural Procedia, 8, 441-448. https://doi.org/10.1016/j.aaspro.2016.02.041

Blazovich, J.L., \& Smith, L.M. (2011). Ethical Corporate Citizenship: Does it Pay? In Research on Professional Responsibility and Ethics in Accounting. 127-163. https://doi.org/10.1108/S1574-0765(2011)0000015008

Baokun L., Tonghui W., Weizhong T., (2013), "Risk Measures and Asset Pricing Models with New Versions of Wang Transform”, in Van-Nam Huynh, Kreinovich V., Sriboonchitta S., Suriya K., Uncertainty Analysis in Econometrics with ApplicationsAdvances in Intelligent Systems and Computing, Volume 200, 2013, pp 155-171.

Bouchet, A., Troilo, M., \& Spaniel, W. (2015). International sourcing, social responsibility and human assets: A framework for labor procurement negotiations in baseball's talent supply chain. Corporate Governance (Bingley), 15(2), 214-228.

https://doi.org/10.1108/CG-09-2014-0108

Boyd, D.E., Spekman, R.E., Kamauff, J.W., \&Werhane, P. (2007). Corporate Social Responsibility in Global Supply Chains: A Procedural Justice Perspective. Long Range Planning, 40, 341-356. https://doi.org/10.1016/j.lrp.2006.12.007

Burchell, J., \& Cook, J. (2006). Confronting the "corporate citizen": Shaping the discourse of corporate social responsibility. International Journal of Sociology and Social Policy, 26(3/4), 121-137. https://doi.org/10.1108/01443330610657188

Byron K. and Khazanchi S. (2012). Reward and Creative Performance: a meta-analytic test of theoretically derived hypotheses. Psychological Bulletin, vol. 138 (4): 809-830. https://doi.org/10.1037/a0027652

Caplan, D., Dutta, S.K., \& Lawson, R.A. (2016). Corporate Social Responsibility Initiatives across the Value Chain. Journal of Corporate Accounting \& Finance, 27(4), 57-66. https://doi.org/10.1002/jcaf.22161

Capriotti, P., \& Moreno, A. (2007). Corporate citizenship and public relations: The importance and interactivity of social responsibility issues on corporate websites. Public Relations Review, 33(1), 84-91. https://doi.org/10.1016/j.pubrev.2006.11.012

Carroll A. (1979). "A three-dimensional conceptual model of corporate performance", Academy Management Review, 4(4), 497-505.

Carter, C.R., \& Jennings, M.M. (2002). Social responsibility and supply chain relationships. Transportation Research Part E, 38(1), 37-52. https://doi.org/10.1016/S1366-5545(01)00008-4

Castello, I., \& Lozano, J. (2009). From risk management to citizenship corporate social responsibility: analysis of strategic drivers of change", Corporate Governance: The International Journal of Business in Society, 9(4), 373-385. https://doi.org/10.1108/14720700910984927

Castka, P., \&Balzarova, M.A. (2008). ISO 26000 and supply chains - on the diffusion of the social responsibility standard. International Journal of Production Economics, 111, 274-286. https://doi.org/10.1016/j.ijpe.2006.10.017

Chen, J., Hu, Q., \& Song J.S. (2016). Supply Chain Models with Mutual Commitments 
and Implications for Social Responsibility. Proceedings of the Nutrition Society, 26(7), 1268-1283. https://doi.org/10.1111/poms.12674

Chi, T. (2011). Building a sustainable supply chain: an analysis of corporate social responsibility (CSR) practices in the Chinese textile and apparel industry. The Journal of the Textile Institute, 102(10), 837-848. https://doi.org/10.1080/00405000.2010.524361

Ciliberti, F., Pontrandolfo, P., \&Scozzi, B. (2008). Investigating corporate social responsibility in supply chains: a SME perspective. Journal of Cleaner Production, 16, 1579-1588. https://doi.org/10.1016/j.jclepro.2008.04.016

Cruz, J.M. (2009). The impact of corporate social responsibility in supply chain management: Multicriteria decision-making approach. Decision Support Systems, 48(1), 224-236. https://doi.org/10.1016/j.dss.2009.07.013

Cruz, J.M. (2013). Mitigating global supply chain risks through corporate social responsibility. International Journal of Production Research, 51(13), 3995-4010. https://doi.org/10.1080/00207543.2012.762134

Cruz, J.M. (2013). Modeling the relationship of globalized supply chains and corporate social responsibility. Journal of Cleaner Production, 56, 73-85. https://doi.org/10.1016/j.jclepro.2011.09.013

Cruz, J.M., \&Wakolbinger, T. (2008). Multiperiod effects of corporate social responsibility on supply chain networks, transaction costs, emissions, and risk. International Journal of Production Economics, 116, 61-74. https://doi.org/10.1016/j.ijpe.2008.07.011

Eriksson, D., \&Svensson, G. (2015). Elements affecting social responsibility in supply chains. Supply Chain Management, 20(5), 561-566.

https://doi.org/10.1108/SCM-06-2015-0203

Faisal M.N. (2007). An Empirical Study of Corporate Social Responsibility in Supply Chains, Asia-Pacific Journal of Management Research and Innovation. 3(2), 77-83. https://doi.org/10.1177/097324700700300208

Ferrell, O.C., Ferrell, L., (2016). Ethics and Social Responsibility in Marketing Channels and Supply Chains: An Overview. Journal of Marketing Channels, 23(1-2), 2-10. https://doi.org/10.1080/1046669X.2016.1147339

Fleishman, A. I. (1978). "A method for simulating non-normal distributions”, Psychometrika, 43(4):521-532.

Forsman-Hugg, S., Katajajuuri, J.-M., Riipi, I., Makela, J., Jarvela, K., \& Timonen, P. (2013). Key CSR dimensions for the food chain. British Food Journal, 115(1), 30-47. https://doi.org/10.1108/00070701311289867

Golan A. (2013), "On the State of the Art of Info-metrics”, in Van-Nam Huynh, Kreinovich V., Sriboonchitta S., Suriya K., Uncertainty Analysis in Econometrics with Applications Advances in Intelligent Systems and Computing, Volume 200, 2013, pp 3-15

Gonzalez-Trejo, E.S., Gonzales-Salazar, N.M., \&Pedroza-Cantu, G., Elizondo-Arroyave, S.G. (2013). Corporate supply chain responsibility (CSCR): Theoretical rationale, research propositions and implementation guidelines. Journal of Management Development, 32(4), 363-375. https://doi.org/10.1108/02621711311326365

Hoejmose, S. U., Grosvold, J., \& Millington, A. (2013). Socially responsible supply chains: Power asymmetries and joint dependence. Supply Chain Management: An International Journal, 18(3), 277-291. https://doi.org/10.1108/SCM-01-2012-0033

Hoejmose, S., Brammer, S., \& Millington, A. (2013). An empirical examination of the relationship between business strategy and socially responsible supply chain management. International Journal of Operations \& Production Management, 33(5), 589-621. https://doi.org/10.1108/01443571311322733 
Hoff-Clausen, E., \&Ihlen, O. (2015). The Rhetorical Citizenship of Corporations in the Digital Age, in Ana Adi , Georgiana Grigore , David Crowther (ed.) Corporate Social Responsibility in the Digital Age (Developments in Corporate Governance and Responsibility, Volume 7) Emerald Group Publishing Limited, pp.17-37.

Hsueh, C. (2008). Equilibrium analysis and corporate social responsibility for supply chain integration. European Journal of Operational Research, 190, 116-129. https://doi.org/10.1016/j.ejor.2007.05.037

Hsueh, C. (2014). Improving corporate social responsibility in a supply chain through a new revenue sharing contract. International Journal of Production Economics, 151, 214-222. https://doi.org/10.1016/j.ijpe.2013.10.017

Hsueh, C. (2015). A bilevel programming model for corporate social responsibility collaboration in sustainable supply chain management. Transportation Research Part E, 73, 84-95. https://doi.org/10.1016/j.tre.2014.11.006

Jallow, K. (2009). Nestlé as corporate citizen: a critique of its Commitment to Africa report. Social Responsibility Journal, 5(4), 512-524. https://doi.org/10.1108/17471110910995375

Jean, R.J., Wang, Z., Zhao, X., \&Sinkovics, R.R. (2016). Drivers and customer satisfaction outcomes of CSR in supply chains in different institutional contexts: a comparison between China and Taiwan. International Marketing Review, 33(4), 514-529.

https://doi.org/10.1108/IMR-04-2014-0115

John E. (1997). Cannibals with Forks: the Triple Bottom Line of the 21st Century Business, Capstone Publishing Ltd., Oxford, UK.

Kazeminia, C.S.C.G.V.S.A. (2015). Does implementing social supplier development practices pay off? Supply Chain Management: An International Journal, 20(4), 389-403. https://doi.org/10.1108/SCM-07-2014-0239

Khurana, K., \&Ricchetti, M. (2016). Two decades of sustainable supply chain management in the fashion business, an appraisal. Journal of Fashion Marketing and Management, 20(1), 89-104. https://doi.org/10.1108/JFMM-05-2015-0040

Kimbro, M.B. \& Cao, Z. (2011). Does voluntary corporate citizenship pay? An examination of the UN Global Compact. International Journal of Accounting \& Information Management, 19(3), 288-303. https://doi.org/10.1108/18347641111169278

Klassen, R.D., \&Vereecke, A. (2012). Social issues in supply chains: Capabilities link responsibility, risk (opportunity), and performance. International Journal of Production Economics, 140(1), 103-115. https://doi.org/10.1016/j.ijpe.2012.01.021

Kogg, B., \& Mont, O. (2012). Environmental and social responsibility in supply chains: The practise of choice and inter-organisational management. Ecological Economics, 83, 154-163. https://doi.org/10.1016/j.ecolecon.2011.08.023

Laksmana, I., \& Yang, Y.W. (2009). Corporate citizenship and earnings attributes. Advances in Accounting, 25(1), 40-48. https://doi.org/10.1016/j.adiac.2009.02.001

Lauriano, L.A., Spitzeck, H., \& Bueno, J.H.D. (2014). The state of corporate citizenship in Brazil. Corporate Governance, 14(5), 598-606.

https://doi.org/10.1108/CG-02-2014-0024

Lawrence, R. (2007). Corporate Social Responsibility, Supply-chains and Saami Claims: Tracing the Political in the Finnish Forestry Industry, Geographical Research, 45(2), 167-176. https://doi.org/10.1111/j.1745-5871.2007.00448.x

Lee, K.H., \& Kim, F.W. (2009). Current status of CSR in the realm of supply management: the case of the Korean electronics industry. Supply Chain Management: an International Journal, 14(2), 138-148. https://doi.org/10.1108/13598540910942000 
Lemke, F., \& Petersen, H.L. (2013). Teaching reputational risk management in the supply chain. Supply Chain Management: An International Journal, 18(4), 413-428. https://doi.org/10.1108/SCM-06-2012-0222

Leppelt, T., Foerstl, K., \& Hartmann, E. (2013). Corporate Social Responsibility in Buyer-Supplier Relationships: Is it Beneficial for Top-Tier Suppliers to Market their Capability to Ensure a Responsible Supply Chain. Business Research, 6(2), 126-152. https://doi.org/10.1007/BF03342746

Letizia, P., \&Hendrikse, G. (2016). Supply Chain Structure Incentives for Corporate Social Responsibility: An Incomplete Contracting Analysis. Production and Operations Management, 25(11), 1919-1941. https://doi.org/10.1111/poms.12585

Lindholm, H., Egels-zandén, N., \&Rudén, C. (2016). Do code of conduct audits improve chemical safety in garment factories? Lessons on corporate social responsibility in the supply chain from Fair Wear Foundation. International Journal of Occupational and Environmental Health, 22(4), 283-291. https://doi.org/10.1080/10773525.2016.1227036

Lund-Thomsen, \&Lindgreen, A. (2014). Corporate Social Responsibility in Global Value Chains: Where Are We Now and Where Are We Going? Journal of Business Ethics, 123(1), 11-22. https://doi.org/10.1007/s10551-013-1796-X

Lund-Thomsen, P., \&Nadvi, K. (2010). Global Value Chains, Local Collective Action and Corporate Social Responsibility: a Review of Empirical Evidence. Business Strategy and the Environment, 19(1), 1-13. http://doi.org/10.1002/bse.670

Mahenthiran, S., Terpstra-Tong, J.L.Y., Terpstra, R., \& Rachagan, S. (2015). Impact of executive citizenship and organizational commitment on corporate social responsibility. Social Responsibility Journal, 11(2), 387-402.

https://doi.org/10.1108/SRJ-04-2013-0040

Mani, V., Agarwal, R., Gunasekaran, A., Papadopoulos, T., Dubey, R., \& Childe, S.J. (2016). Social sustainability in the supply chain: Construct development and measurement validation. Ecological Indicators, 71, 270-279. https://doi.org/10.1016/j.ecolind.2016.07.007

Manning, L. (2013). Corporate and consumer social responsibility in the food supply chain. British Food Journal, 115(1), 9-29. https://doi.org/10.1108/00070701311289858

McAllister, M.L., Fitzpatrick, P., \& Fonseca, A. (2014). Challenges of space and place for corporate 'citizens' and healthy mining communities: The case of Logan Lake, BC and Highland Valley Copper. The Extractive Industries and Society, 1(2), 312-320. https://doi.org/10.1016/j.exis.2014.04.005

McCorkindale, T. (2008). Does familiarity breed contempt? Analyses of the relationship among company familiarity, company reputation, company citizenship, and company personality on corporate equity. Public Relations Review, 34(4), 392-395. https://doi.org/10.1016/j.pubrev.2008.09.014

Mefford R. (2011). The Economic Value of Sustainable Supply Chain. Business and Society Review. Vol. 16 (1): 109-143. https://doi.org/10.1111/j.1467-8594.2011.00379.x

Miroshnik, V. (2012). Company citizenship creation in the developing countries in the era of globalization: Evidence from the Toyota Motor Company in India. Journal of Management Development, 31(7), 672-690. https://doi.org/10.1108/02621711211243872

Mohan, N., Panda, S., Sankar, S., \&Basu, M. (2014). Corporate social responsibility, coordination and profit distribution in a dual-channel supply chain. Pacific Science Review, 16(4), 235-249. https://doi.org/10.1016/j.pscr.2015.05.001

Mont, O., \&Leire, C. (2009). Socially responsible purchasing in supply chains: drivers and barriers in Sweden. Social Responsibility Journal, 5(3), 388-407. 
https://doi.org/10.1108/17471110910977302

Moreno, L. (2010). Welfare mix, CSR and social citizenship. International Journal of Sociology and Social Policy, 30(11/12), 683-696. https://doi.org/10.1108/01443331011085268

Morgan, G., Ryu, K., \&Mirvis, P. (2009). Leading corporate citizenship: governance, structure, systems, Corporate Governance. The international Journal of Business Society, 9(1), 39-49. https://doi.org/10.1108/14720700910936047

Myers, C., \&Lariscy, R. (2014). Corporate PR in a post-citizens united world. Journal of Communication Management, 18(2), 146-157. https://doi.org/10.1108/JCOM-01-2013-0001

Mzembe, A.N., Lindgreen, A., Maon, F., \&Vanhamme, J. (2016). Case Study of Eastern Produce Limited in Malawi. Corporate Social Responsibility and Environmental Management Corp., 178(March 2015), 165-178. https://doi.org/10.1002/csr.1370

New, S.J. (2015). Modern slavery and the supply chain: the limits of corporate social responsibility? Supply Chain Management, 20(6), 697-707.

https://doi.org/10.1108/SCM-06-2015-0201

Ni, D., \& Li, K.W. (2012). A game-theoretic analysis of social responsibility conduct in two-echelon supply chains. International Journal of Production Economics, 138(2), 303-313. https://doi.org/10.1016/j.ijpe.2012.04.002

Ni, D., Li, K.W., \& Tang, X. (2010). Social responsibility allocation in two-echelon supply chains: Insights from wholesale price contracts. European Journal of Operational Research, 207(3), 1269-1279. https://doi.org/10.1016/j.ejor.2010.06.026

Nutley, S. M. and H. T. O. Davies (2002). Evidence-based Policy.

Panda, S., \&Modak, N.M. (2016). Exploring the effects of social responsibility on coordination and pro fi t division in a supply chain. Journal of Cleaner Production, 139, 25-40. https://doi.org/10.1016/j.jclepro.2016.07.118

Panda, S., Modak, N.N., \& Pradhan, D. (2014). Corporate social responsibility, channel coordination and profit division in a two-echelon supply chain. International Journal of Management Science and Engineering Management, 11(1), 22-33. https://doi.org/10.1080/17509653.2014.968815

Patrizia, J., Airike, R.P., \& Mark-herbert, C. (2014). Exploring Political Corporate Social Responsibility in Global Supply Chains Business for Social Responsibility Swedish Society for Nature Conservation. Journal of Business Ethics, 125, 581-599. https://doi.org/10.1007/s10551-013-1927-4

Pedersen, E.R., \& Andersen, M. (2006). Safeguarding corporate social responsibility (CSR) in global supply chains: how codes of conduct are managed in buyer-supplier relationships. Journal of Public Affairs, 6(November), 228-240.

Perry, P., \& Towers, N. (2013). Conceptual framework development. International Journal of Physical Distribution \& Logistics Management, 43(5/6), 478-501. https://doi.org/10.1108/IJPDLM-03-2012-0107

Petrovic - Lazarevic, S. (2010). Good corporate citizenship in the Australian construction industry. Corporate Governance: The International Journal of Business in Society, 10(2), 115-128. https://doi.org/10.1108/14720701011035648

Pishvaee, M.S., Razmi, J., \&Torabi, S.A. (2012). Robust possibilistic programming for socially responsible supply chain network design: A new approach. Fuzzy Sets and Systems, 206, 1-20. https://doi.org/10.1016/j.fss.2012.04.010

Quarshie, A.M., Salmi, A., \&Leuschner, R. (2016). Journal of Purchasing \& Supply Management Sustainability and corporate social responsibility in supply chains: The state of 
research in supply chain management and business ethics journals. Journal of Purchasing and Supply Management, 22(2), 82-97. https://doi.org/10.1016/j.pursup.2015.11.001

Rahbek Pedersen, E. (2009). The many and the few: rounding up the SMEs that manage CSR in the supply chain. Supply Chain Management: An International Journal, 14(2), 109-116. https://doi.org/10.1108/13598540910941975

Sadler, D., \& Lloyd, S. (2009). Neo-liberalising corporate social responsibility: A political economy of corporate citizenship. Geoforum, 40(4), 613-622. https://doi.org/10.1016/j.geoforum.2009.03.008

Schinckus C. (2018), When Physicists become undisciplined: An Essay on Econophysics, PhD Dissertation in History and Philosophy of Science, University of Cambridge, UK.

Shinkle, G.A., \& Spencer, J.W. (2012). The social construction of global corporate citizenship: Sustainability reports of automotive corporations. Journal of World Business. 47(1), 123-133. https://doi.org/10.1016/j.jwb.2011.02.003

Shukla, A.C., Deshmukh, S.G., \& Kanda, A. (2009). Environmentally responsive supply chains. Journal of Advances in Management Research, 6(2), 154-171.

Singh, V., Vinnicombe, S., \&Kumra, S. (2006). Women in formal corporate networks: an organisational citizenship perspective. Women in Management Review, 21(6), 458-482. https://doi.org/10.1108/09649420610683462

Smith, N.C., Palazzo, G., \& Bhattacharya, C.B. (2010). Marketing's consequences: stakeholder marketing and supply chain corporate social responsibility issues. Business Ethics Quarterly, 20(4), 617-641.

Solitander, H.H.N. (2013). Corporate social responsibility as relief from responsibility NPO legitimizations for corporate partnerships in contested terrains. International Journal of Contemporary Hospitality, 13(1), 2-22.

Solomon, L., \& Nelson, T. (2013). Energy for Life - an evidence - based approach to corporate citizenship. Sustainability Accounting, Management and Policy Journal, 4(2), 236-258. https://doi.org/10.1108/SAMPJ-Oct-2012-0034

Soni, G., \&Kodali, R. (2011). A Critical Analysis of Supply Chain Management Content in Empirical Research. Business Process Management Journal, 17(2), 238-266. https://doi.org/10.1108/14637151111122338

Spence, L., \&Bourlakis, M. (2009). The evolution from corporate social responsibility to supply chain responsibility: the case of Waitrose. Supply Chain Management: An International Journal, 14(4), 291-302. https://doi.org/10.1108/13598540910970126

Strand, R., (2009). Corporate Responsibility in Scandinavian Supply Chains Corporate Responsibility in Scandinavian Supply Chains. Journal of Business Ethics, 85(1), 179-185. https://doi.org/10.1007/s10551-008-9937-3

Strugatch, W. (2011). Turning values into valuation: Can corporate social responsibility survive hard times and emerge intact? Journal of Management Development, 30(1), 44-48. https://doi.org/10.1108/02621711111098352

Tate, W.L., Ellram, L.M., \&Kirchoff, J.O.N.F. (2010). Corporate Social Responsibility Reports: A Thematic Analysis Related To Supply Chain Management University of Tennessee. Journal of Supply Chain Management, (January), 19-44. http://doi.org/10.1111/j.1745-493X.2009.03184.x

Tencati, A., Russo, A., \&Quaglia, V. (2010). Sustainability along the global supply chain: the case of Vietnam. Social Responsibility Journal, 6(1), 91-107. https://doi.org/10.1108/17471111011024577

Tiwari, A., Turner, C., \&Younis, K. (2014). Socially responsible purchasing in the auto- 
motive industry. Social Responsibility Journal, 10(4), 620-645.

https://doi.org/10.1108/SRJ-05-2012-0056

Towers, N., Perry, P., \& Chen, R. (2013). Corporate social responsibility in luxury manufacturer supply chains: An exploratory investigation of a Scottish cashmere garment manufacturer. International Journal of Retail \& Distribution Management, 41(11), 961-972. https://doi.org/10.1108/IJRDM-05-2013-0100

Tuan, L.T. (2016). From cultural intelligence to supply chain performance. The International Journal of Logistics Management, 27(1), 95-121. https://doi.org/10.1108/IJLM-01-2014-0009

Tudor, T.L, Bannister, S., Butler, S., White, P., Jones, K., Woolridge, A.C., Bates, M.P., \& Philips, P.S. (2008). Can corporate social responsibility and environmental citizenship be employed in the effective management of waste? Case studies from the National Health Service (NHS) in England and Wales. Resources, Conservation and Recycling, 52(5), 764-774. https://doi.org/10.1016/j.resconrec.2007.11.006

Wade, J.A. (2011). Chapter 6-Stakeholders, ethics and social responsibility in the food supply chain. Food Supply Chain Management: Issues for the hospitality and retail sectors. 111-124. https://doi.org/10.1016/B978-0-7506-4762-5.50010-9

Walker, M., \& Parent, M.M. (2010). Toward an integrated framework of corporate social responsibility, responsiveness, and citizenship in sport. Sport Management Review, 13(3), 198-213. https://doi.org/10.1016/j.smr.2010.03.003

Walters, G., \& Chadwick, S. (2009). Corporate citizenship in football: delivering strategic benefits through stakeholder engagement. Management Decision, 47(1), 51-66. https://doi.org/10.1108/00251740910929696

Wang S. (1996). Premium Calculation by Transforming the Layer Premium Density. ASTIN Bulletin, 26, 71-92.

Wang, C.J. (2014). Do ethical and sustainable practices matter? Effects of corporate citizenship on business performance in the hospitality industry. International Journal of Contemporary Hospitality Management, 26(6), 930-947. https://doi.org/10.1108/IJCHM-01-2013-0001

Weaver, G.R., Trevino, L.K., \& Cochran, P.L. (1999). Integrated and decoupled corporate social performance; management commitments, external pressures, and corporate ethics practices. Academy of Management Review 42(5), 539-552. http://www.jstor.org/stable/256975

Wiese, A., \&Toporowski, W. (2013). CSR failures in food supply chains-an agency perspective. British Food Journal, 115(1), 92-107. https://doi.org/10.1108/00070701311289894

Young, S. B., Fonseca, A., \& Dias, G. (2010). Principles for responsible metals supply to electronics. Social Responsibility Journal, 6(1), 126-142. https://doi.org/10.1108/17471111011024595

Zehir, C., Muceldili B., \&Zehir, S. (2012). The Impact of Corporate Entrepreneurship on Organizational Citizenship Behavior and Organizational Commitment: Evidence from Turkey SMEs. Procedia-Social and Behavioral Sciences, 58, 924-933. https://doi.org/10.1016/j.sbspro.2012.09.1071

Zhang, Z., Wan, D., \&Jia, M. (2008). Do high-performance human resource practices help corporate entrepreneurship? The mediating role of organizational citizenship behavior. The Journal of High Technology Management Research, 19(2), 128-138. https://doi.org/10.1016/j.hitech.2008.10.005 